\title{
Parental Involvement and Students' Academic Performance in Public Day Secondary Schools in Bumula Sub-County, Kenya
}

\author{
Sarah Likoko, Jane Barasa, Ismael Mabunde \\ Department of Educational Planning and Management, Kibabii University, Kenya
}

\begin{abstract}
This study investigated the influence of parental involvement on student's academic performance. Simple random sampling was used to select 352 form four students from a sample of 13 public day secondary schools in Bumula sub-County. The data was analyzed using percentages, weighted averages, means and one way ANOVA. The study established that parental involvement play a significant role in influencing the academic performance of the students in public day secondary schools.
\end{abstract}

Keywords: Academic, Parental, Involvement, Performance, Students

\section{INTRODUCTION}

$\mathrm{C}$ hildren whose parents are better qualified than children who have less interest in parents ' education have higher rates of academic success. The effect of parent engagement on the progress of universities was not only among academics but also among politicians who integrate attempts to improve parent interest in larger educational policy initiatives. However, research has not clearly indicated at what level and stage of a learner where parental involvement is crucial. This study addresses the gap by focusing on parental involvement on student academics at public day secondary schools.

Nadenge (2015) investigated the impacts of family socioeconomic background on student educational performance in certain high schools in Nairobi using descriptive design. A sample of 125 respondents was selected for the study and questionnaires and interviews were done. It emerged that there exists significant positive correlation between parental involvements in their student's academic performance. However, generalizability of the Nadenge (2015) findings could be done with a lot of caution since the social environment in Nairobi County is different from rural set ups. The current study sought to fill these glaring gap.

Lv (2016), in a similar study, conducted research on the connection between academic accomplishment in China and the positive and negative emotional health of children from primary schools and the moderating impact of parent/school interaction There were 419 students from elementary schools with their parents. The positive and negative effect of elementary students, their academic achievements in medium and final exams of the current semester and the level of contact between parents and schools were evaluated. This dynamic was greatly moderated by parent-school contact. Such results indicate that parental involvement with schools has an effect on Chinese learners' academic achievements and subjective welfare. Since, Lv (2016) focused on schools in China where education system is more advanced compared to developing countries including Kenya, generalization of findings was to be done with a lot of caution. This gap will be addressed by this study.

The impact on the academic performance of mixed-day high schoolers in Kuresoi in Kenya was also investigated by Koskei (2014). The research used former style. Random sampling technique was applied by the researcher. Six secondary schools and 180 form four learners were sampled. Questionnaires collected the data used. The quality of the research instrument was determined by the experts. The scientist performed an analysis of the literature in question. Descriptive or inferential statistics, null hypotheses checked with $\alpha=0.05$ were used to evaluate the data obtained in the region. The study discovered that parental participation in schooling did not affect the academic performance of students in Kuresoi district significantly. The weakness of Koskei (2014) study is that it employed divide half method in determining reliability which fails to explain measurement error exclusive to a particular testing occasion. The current study employed test-retest method to fill the gap.

Topor et al. (2011) also examined the child's perception of cognitive abilities and the quality of the relationship between student and teacher. 158 participants compromising mothers and teachers aged seven years took part. In addition to the influence of the child's intelligence, the findings showed a significant correlation between parents' participation and child university success. It emerged that the child is fully mediated by the perception of the cognitive ability of the parent' involvement in a standardized test. The consistency of the association between teacher and student completely mediated the connection between parent engagement and the academic success of the child in the classroom. However, the generalizability of the findings to other populations especially adolescents could be done with a lot of caution due the difference in sample characteristics as Topor et al., (2011) focused on seven (7) year old children. 
Amponsah et al., (2018) explored the link both in education and academic achievement in a more recent study between the parental involvements of high school students in the Ashanti Mampon Municipality of Ghana. The study was conducted with descriptive research design for correlations. A stratified random sampling procedure consisting of 186 men and 285 women was used to select the total sample of 471 respondents. The tools used to collect data for this thesis were questionnaires and test pieces on mathematics and English. Data analysis was carried out using the concept of statistical tools (mean and standard deviations) in order to analyze the perceived student academic performance and interest in their learning, while a zero-order analysis was used to examine the ties entre the parental contribution in education and academic progress. The findings of the study indicate that the parental contribution to education and the academic successes of the students are strongly optimistic. However, the generalization of the findings to other populations especially schools in Kenya was limited, since they operate in different geographical settings, a gap that this study sought to address.

Mutodi and Ngirande (2014) purposed to quantitatively ascertain the impacts of parents being involved in their childrens academics and the subsequent performance in mathematics in South Africa. A questionnaire was administered to 114 parents to gather information. 44 male parents and 70 female parents were the sample for the study. Percentages, t-test and ANOVA were used in analysis. The findings revealed that parental support is a noteworthy factor in student's academic performance. However, generalizability of Mutodi and Ngirande (2014) findings was limited, since they focused only one aspect of learning (students' performance in Mathematics). Therefore to fill the gap, the current study considered academic performance in general.

Mwirichia (2013) descriptively examined the effect of parental participation on academic achievement in Meru County, Kenya, pre-school baby. Data collection was performed using questionnaires, record review and interview schedules. 166 respondents were chosen for their sample size. Families, teachers and children were interviewed. Descriptives like frequency, mean values and tables and graphs were used to interpret the data. The study concluded that parental involvement in educational activities of the child had direct influence. However, descriptive studies cannot test or verify the research problem statistically. These could pose a limitation in terms of generalizability of the findings to other populations or settings. Therefore the current study sought to fill the gap by adopting ex- post facto design.

\section{RESULTS AND DISCUSSION}

\subsection{Parental Involvement and Students' Academic Performance}

The null hypothesis below was tested to achieve this objective.

$\mathbf{H}_{\mathbf{o}}$ : Parental involvement has no statistically significant influence on student's academic performance.

To determine the extent of parental involvement, respondents were asked to rate on a 5-point likert scale based on given statements. These were analyzed using weighted averages.

Table 1: Student Opinions on Influence of Parental Involvement on Academics

\begin{tabular}{|c|c|c|c|c|c|c|c|c|}
\hline Statement & $\mathbf{S A}$ & $\mathbf{A}$ & $\begin{array}{l}\mathbf{N} \\
\mathbf{S}\end{array}$ & D & $\begin{array}{l}\text { S } \\
\mathbf{D}\end{array}$ & $\Sigma f i$ & $\Sigma f i w i$ & $\frac{\Sigma f i w i}{\Sigma f i}$ \\
\hline $\begin{array}{l}\text { Parents have } \\
\text { set target } \\
\text { which } \\
\text { student must } \\
\text { strive to } \\
\text { achieve }\end{array}$ & 20 & 161 & 16 & 119 & 4 & 320 & 1034 & 3.2313 \\
\hline $\begin{array}{l}\text { Parents have } \\
\text { close } \\
\text { communicati } \\
\text { on with class } \\
\text { teacher over } \\
\text { student } \\
\text { academics }\end{array}$ & 87 & 109 & 32 & 75 & 17 & 320 & 1134 & 3.5438 \\
\hline $\begin{array}{l}\text { Parents } \\
\text { monitor } \\
\text { student } \\
\text { academic } \\
\text { progress }\end{array}$ & 68 & 124 & 32 & 79 & 17 & 320 & 1107 & 3.4594 \\
\hline $\begin{array}{c}\text { Parents } \\
\text { regularly } \\
\text { check } \\
\text { assignment }\end{array}$ & 41 & 56 & 14 & 201 & 8 & 320 & 881 & 2.7531 \\
\hline $\begin{array}{l}\text { Parents } \\
\text { keenly } \\
\text { attend } \\
\text { academic } \\
\text { days in } \\
\text { school }\end{array}$ & 29 & 138 & 10 & 131 & 12 & 320 & 1001 & 3.1281 \\
\hline
\end{tabular}

Source: Field Data (2020)

$181(55 \%)$ of the respondents agreed that parents had set targets which they had to strive to achieve while 123 (36.8\%) generally disagreed and $16(8.1 \%)$ indicated being Not Sure. The weighted average for the statement was 3.2313 , which imply on average a slight majority of the students' parents set targets for the learners.

On whether parents had close communication with class teachers over student academics, $196(52.5 \%)$ of the respondents agreed while $92(45 \%)$ disagreed and $32(2.5 \%)$ indicated not being sure about the statement. The weighted average of the statement was 3.5438 which imply generally most parents of the students included in the study communicate with class teacher indicating parent involvement. Students whose parents keep in touch with class teachers stand a higher chance of improving in academics. 
When asked to indicate their opinion on whether parents monitor the academic progress of the students, majority of the respondents of $192(60 \%)$ agreed while $96(30 \%)$ disagreed and $32(10 \%)$ were Not Sure about the statement. The statement had a weighted average of 3.4594 which indicated that on average, majority of the parents of the students actually monitor the progress of the students.

To further assess parental involvement, the students were required to rate their opinion on whether their parents regularly check assignments. A larger proportion represented by $209(65.3 \%)$ disagreed with the statement while only 97 $(30.3 \%)$ agreed with the statement. A small proportion of 14 (4.4\%) indicated being not sure about the statement. The weighted average was 2.7531 hence on average parents do not check assignments of the students indicating little involvement.

The students were required to rate opinion on whether parents keenly attend academic days in schools. There was a fairly divided opinion on the statement with $167(52.2 \%)$ agreeing while $143(44.7 \%)$ disagreeing and $10(3.1 \%)$ indicating not sure about the statement. Hence the weighted average was 3.1281 which imply the students on average fairly agree that parents attend academic days.

\subsection{Aggregation of Variables on Parental Involvement}

The ratings of each student respondent for the set of items that measured each variable were summed up to obtain an index which measured the level of involvement by parents in the academics of the student. The index for parental involvement had values between 5 and 25 . An index value of 5 indicated least rating while 25 indicated maximum rating. Ratings above 12 indicated high ratings for parental involvement, while ratings below 12 imply low levels of parental involvement.

Table 2: Descriptive Statistics of Aggregated Variables on Parental Involvement

\begin{tabular}{|c|c|c|c|c|c|c|c|c|}
\hline $\mathrm{N}$ & Min. & Max & Mean & $\begin{array}{c}\text { Std. } \\
\text { Dev }\end{array}$ & $\begin{array}{c}\text { Skewn } \\
\text { ess }\end{array}$ & $\begin{array}{c}\text { Std. } \\
\text { Error }\end{array}$ & $\begin{array}{c}\text { Kurto } \\
\text { sis }\end{array}$ & $\begin{array}{c}\text { Std. } \\
\text { Error }\end{array}$ \\
\hline 320 & 8.00 & $\begin{array}{c}23.0 \\
0\end{array}$ & $\begin{array}{c}16.115 \\
6\end{array}$ & $\begin{array}{c}4.342 \\
23\end{array}$ & -.125 & .136 & - & 1.322 \\
.272 \\
\hline
\end{tabular}

Source: SPSS output

The descriptive statistics indicate that the index for Parental Involvement had a mean of 16.1156 with a standard deviation of 4.34223 which on average imply that there was a significant involvement by parents in the academics of their students in the schools under study.

\subsection{Hypothesis Testing for Influence of Parental Involvement on Student Academic Performance}

In order to verify the hypothesis, $\mathbf{H}_{\mathbf{0}}$ that 'there is no statistically significant influence of parental involvement on student academic performance', the parental involvement index for low achieving students and high achieving students included in the study were considered independently. The One way Analysis Of Variance inferential method of analysis was used to determine the significant differences in the levels of parental involvement between the high achieving and low achieving students that were included in the study. Table 3 shows the descriptive statistics for the groups of students.

Table 3: Descriptive Statistics for Parental Involvement Index for Different Student Groups

\begin{tabular}{|c|c|c|c|c|c|c|c|c|}
\hline & \multirow[t]{2}{*}{$\mathrm{N}$} & \multirow[t]{2}{*}{ Mean } & \multirow{2}{*}{$\begin{array}{l}\text { Std. } \\
\text { Dev }\end{array}$} & \multirow{2}{*}{$\begin{array}{c}\text { Std. } \\
\text { Err } \\
\text { or }\end{array}$} & \multicolumn{2}{|c|}{$\begin{array}{c}95 \% \\
\text { Confidence } \\
\text { Interval } \\
\text { for Mean }\end{array}$} & \multirow[t]{2}{*}{ Min } & \multirow[t]{2}{*}{ Max } \\
\hline & & & & & $\begin{array}{c}\text { Lowe } \\
\text { r } \\
\text { Boun } \\
d\end{array}$ & $\begin{array}{l}\text { Upper } \\
\text { Boun } \\
\text { d }\end{array}$ & & \\
\hline $\begin{array}{l}\text { Low } \\
\text { Achiev } \\
\text { ers }\end{array}$ & 160 & $\begin{array}{c}13.10 \\
62\end{array}$ & $\begin{array}{c}3.5370 \\
4\end{array}$ & $\begin{array}{l}.27 \\
963\end{array}$ & $\begin{array}{c}12.55 \\
40\end{array}$ & $\begin{array}{c}13.65 \\
85\end{array}$ & 8.00 & 23.00 \\
\hline $\begin{array}{l}\text { High } \\
\text { Achiev } \\
\text { ers }\end{array}$ & 160 & $\begin{array}{c}19.12 \\
50\end{array}$ & $\begin{array}{c}2.6629 \\
3\end{array}$ & $\begin{array}{l}.21 \\
052\end{array}$ & $\begin{array}{c}18.70 \\
92\end{array}$ & $\begin{array}{c}19.54 \\
08\end{array}$ & $\begin{array}{c}11.0 \\
0\end{array}$ & 23.00 \\
\hline Total & 320 & $\begin{array}{c}16.11 \\
56\end{array}$ & $\begin{array}{c}4.3422 \\
3\end{array}$ & $\begin{array}{l}.24 \\
274\end{array}$ & $\begin{array}{c}15.63 \\
81\end{array}$ & $\begin{array}{c}16.59 \\
32\end{array}$ & 8.00 & 23.00 \\
\hline
\end{tabular}

Source: SPSS Output

There was a higher mean rating on Parental Involvement Index by High achieving students with $\mathrm{m}=19.1250$, sd $=$ 2.6629 and lower ratings for Low achieving students $(\mathrm{m}=$ 13.1062 , sd $=3.53704$ ).

The next section of the output reveals the results of the one way ANOVA computed between the higher achieving and low achieving students.

Table 4: One way ANOVA for differences in Parental Involvement Index between High Achieving and Low Achieving Students

\begin{tabular}{|c|c|c|c|c|c|}
\hline & $\begin{array}{c}\text { Sum of } \\
\text { Squares }\end{array}$ & Df & $\begin{array}{c}\text { Mean } \\
\text { Square }\end{array}$ & F & Sig. \\
\hline $\begin{array}{c}\text { Betwe } \\
\text { en } \\
\text { Groups }\end{array}$ & $\begin{array}{c}2898.02 \\
8\end{array}$ & 1 & $\begin{array}{c}2898.0 \\
28\end{array}$ & $\begin{array}{c}295.6 \\
89\end{array}$ & .000 \\
\hline $\begin{array}{c}\text { Within } \\
\text { Groups }\end{array}$ & $\begin{array}{c}3116.69 \\
4\end{array}$ & 318 & 9.801 & & \\
\hline Total & $\begin{array}{c}6014.72 \\
2\end{array}$ & 319 & & & \\
\hline
\end{tabular}

Source: SPSS Output

A one way ANOVA computed to determine differences in Parental Involvement Index between the high achieving and low achieving students found a significant difference in the ratings $\left(F_{(1,318)}=295.689, \rho<0.05\right)$. High achieving students highly rated Parental involvement $(m=$ $19.1250, s d=2.6629)$ than low achieving students $(m=$ $13.1062, s d=3.53704)$. 
The current study rejected the null hypothesis, $\mathbf{H}_{\mathbf{0}}$ that the 'parental involvement has no statistically significant influence on student's academic performance'. Implying that parental involvement in student academics significantly influences the student academic performance. Therefore, parents' involvement at every stage in the learning process of a child remains important. The more parents involve with their children academics, the higher the performance.In these regard, parents need to own the education process of their children through, setting targets that their children needs to strive to meet, closely communicate with class teacher over student academics, monitor student academic progress, regularly check assignment and keenly attend academic days in schools, all these will yield good academic performance for the sub County.

The findings concur with Lara \& Saracostti (2019) who established that children whose academic success in schools is lower than that of children display discrepancies between parental participation profiles, which show that children whose parents have a low performance in Chile. Although there were similarities in the findings, Lara \&Saracostti (2019) study findings were limited to the generalizability to other populations or settings especially, as Chile's education system is more advanced compared to developing countries like Kenya.

\section{CONCLUSION}

From the findings of the study, it can be concluded that parental involvement positively influences student academic performance. Implying that low academic performance associated with public day secondary schools in the Country, can largely be attributed to the inactive participation of parents in school matters.

\section{RECOMMENDATION}

The study recommended that public day secondary schools should create more programmes that can involve parents in monitoring student academic work.

\section{REFERENCES}

[1] Koskei, B. K.(2014). Influence of Parental Involvement on Students' Academic Performance of Public Mixed Day Secondary Schools in Kuresoi Sub-County, Nakuru County, Kenya. International Journal of Education and Research Vol.2 No. 12 December 2014, pg.505

[2] Lv, B., Zhou, H., Guo, X ., Liu, C., Liu, 'Z., \&Luo, L.(2016). The Relationship between Academic Achievement and the Emotional Well-Being of Elementary School Children in China: The Moderating Role of Parent-School Communication.Front.Psychol., 24June 2016 https://doi.org/10.3389/fpsyg.2016.00948

[3] Nadenge, M.G.(2015). "Relationship between Parental Socioeconomic Status and Student Academic Achievement: The Case of Selected Secondary Schools in Urban Informal Settlements in Westlands Division, Nairobi County". Masters Published Thesis, University of Nairobi

[4] Topor, D.R.,Keane,S.P., Shelton,T.L,\&Calkins, S. D.(2011).Parent involvement and student academic performance: A multiple mediational analysis. HHS Author Manuscripts, PMC302009 